\title{
BIOCHEMICAL EFFECTS OF SOME COMMONLY USED LEGUMES ON ALLOXAN DIABETIC RATS
}

\author{
By
T. A. Hafez ; S. M. A. Azma ; H. A. Nada and
N. M. Ismail

From

Biochemistry Department, Faculty of Medicine, Mansoura University. Received for Puplication : 7/3/1990.

\section{INTRODUCTION}

Previous investigation showed that alloxan partially destroys the pancreatic islets of langerhans House, (1958), and is being used experimentally to induce diabetes in rodents. Alloxan changed the uitra structure of rats islets similarly as in rabbits Williamson and Lacy, (1959), leading to insulin deficiency and consequently hyperglycemia, glucosuria and decreased glycogen content in the aniinal body Scarborough, (1970), as well as disturbance in lipid metabolism Martin et al., (1983).

It was reported by some research workers that feeding on diet containing raw legumenous seeds as raw soy been with a naturally high trypsin inhibitor content developed hypertrophy of the acinar cells of exocrine pancreas Melmed et al., (1973), and may lead to the recovery of the destructed beta-cells caused by alloxan Ibrahim et al., (1979).

Jenkins et al. (1978), found that leguminous seeds fibers has been used successfully in the diet to reduce glucosuria in diabetics.

Anderson, (1979), found that such diet have successfully reduced serum triglycerides concentration in hypertriglyceridaemic men.

Miranda and Horwitz (1978), suggested that it is possible to achieve substantial lowering of blood glucose level of diabetic patients by increasing dietary fibre content, without the need for increasing insulin.

Roy and Schneemen (1981), showed that dietary vegetable protein especially soy group lowered plasma cholesterol compared to animal proteins. Soy proteins were found to posMANSOURA MEDICAL JOURNAL 


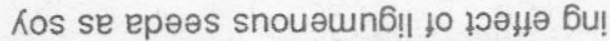

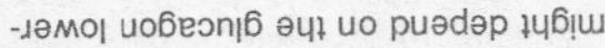

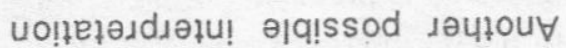

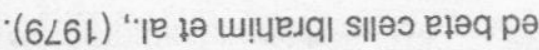

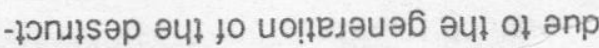

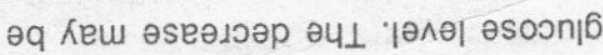

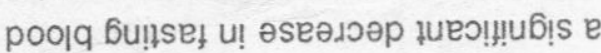

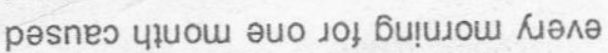

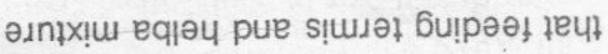

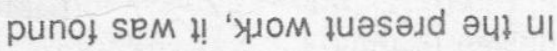

\section{NOISSnכSIa}

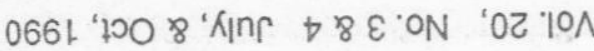
-дәло рәңsе! әләм sјeu!u pa!!ueos

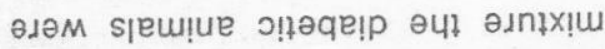

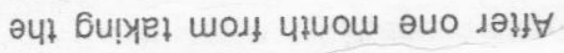

чนһ

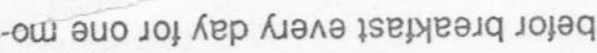

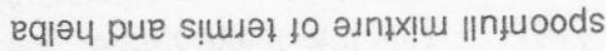

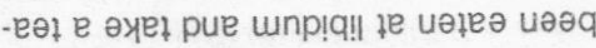

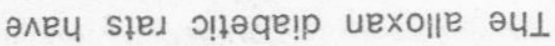

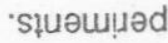

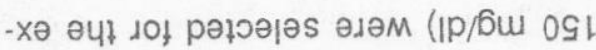
әлоqе әsoon!6 poolq 6u!nseı) uexol

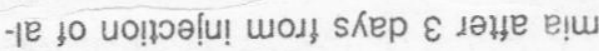
-әеэКБләdКц рәмоцs чगччм słey

(II)

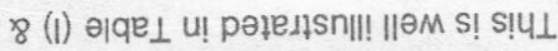

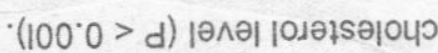
$-7 \mathrm{aH}$ u! әsеәдои! Һиеग!! 's|әлә| ( $200.0>$ d) 70$]^{\prime \prime}$ ' (ร0.0 > d)

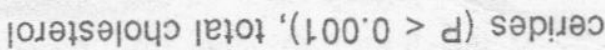

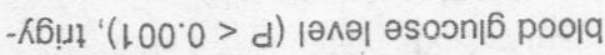

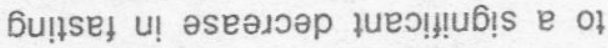

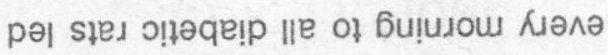

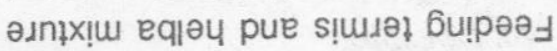

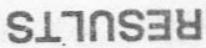

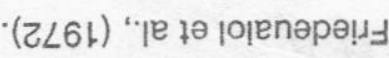

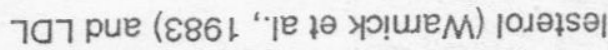

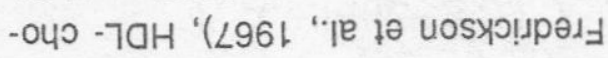

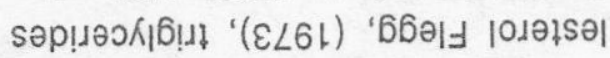

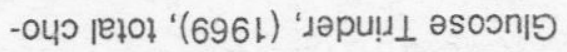

: , 10 uo!̣eس!̣s

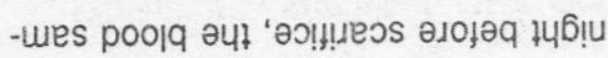

บอ!ฺ่อว

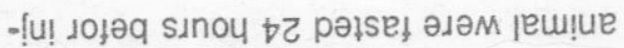

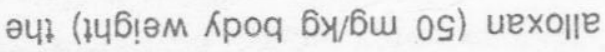

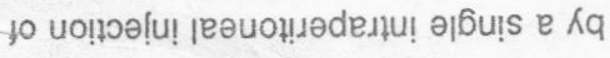

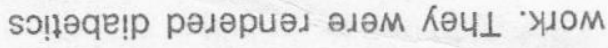

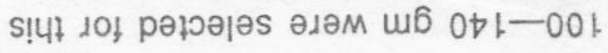

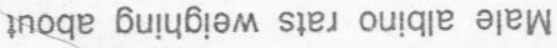

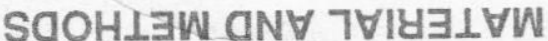

sien

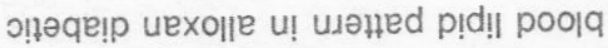
pue ґәлә әsoวn! 6 poolq bu!ıse! uo

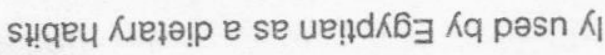

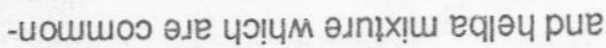

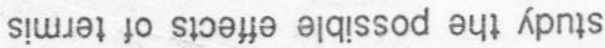

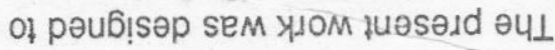

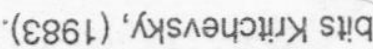

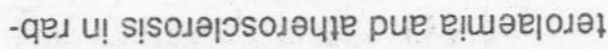

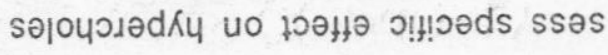


been in diabetic rats Madar, (1983), which enhance glucose utilization.

This results agree with that reported by Mahalko et al. (1984) \& Madar et al., (1985).

This results is contradect to Jenkins et al., (1980) who reported that legumenous seeds are one of the high fibre foods which cause only nonsignificant rise in the blood glucose level.

It was found that feeding Termis and Helba mixture everymorning for one month caused a significant decrease in serum triglycerides, total cholesterol as well as LDL levels. These results are in agreement with many reports.

Grand et al, (1974), reported that dried legumes diet have succesafully reduced serun triglycerides concentration in hypertriglyceridaemic men.

Maurive \& Jensen (1978) and Madar (1983), reported that soy been feeding caused a significant drop in liver and plasma triglycerides and cholest-erol.

There is a significant increase in $\mathrm{HDL}$-cholesterol, this result is in agreement with Jenkins et al, (1983), they reported that soy bsen protein share in composition of HDL.
Many mechanisms are available to explain the hypocholesterolemic action of dried legrumes as soy been and termis, among which are the suppression of cholesterol biosynthesis (Qureshi et al., 1983), the increase in cholesterol excretion (Chang $\hat{\&}$ Ohn. son, 1977), and increase catabolism (Kritchevsky, 1983).

A sharp decrease in total cholesterol accompanied by a rise in HDLcholesterol suggest the improvement of cholesterol metabolism.

In conclusion, the promising results in the improvement of fasting blood glucose level and blood lipid pattern of diabetic rats kept on feeding termis and helba mixture everymorning. And it is a good habit for the diabetic patients to take a mixture of termis and helba every morning before breakfast : What remain to be elucidated is to understand the nature of the chemical agents of this mixture that may be responsible for that observation, as well as the histopathological study of Bcells of pancreas and serum insulin level before and after mixture intake to prove the mechanism of actions. These points must be done in further investigation.

MANSOURA MEDICAL JOURNAL 


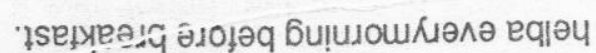

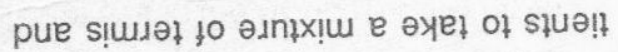

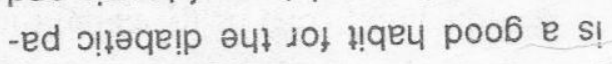

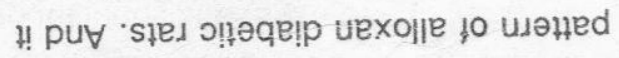
p!d!! poolq pue ןәлә| әsoon!b poolq

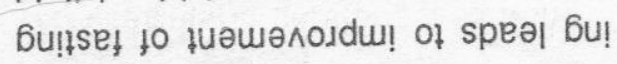

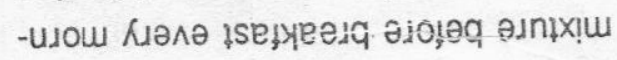

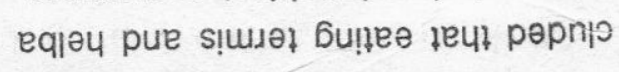

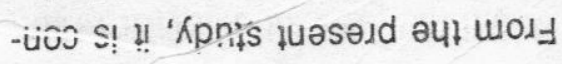

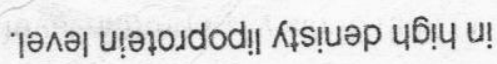

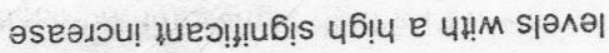

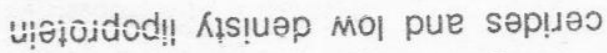

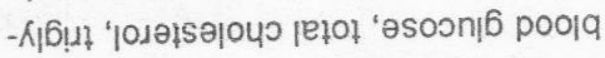

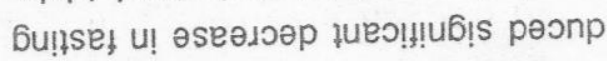

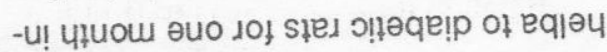

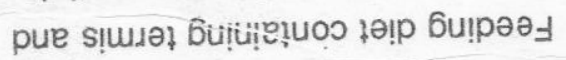

sten

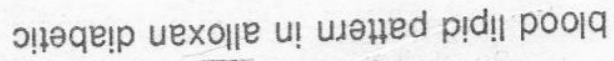
pue ґәлә| әsoonj6 poolq bu!nset uo

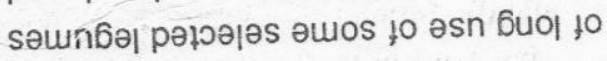

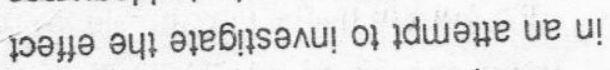

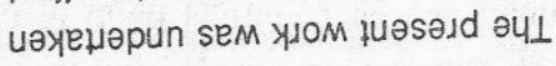

NOISกาวNOว aN ม $4 \forall$ WWกS

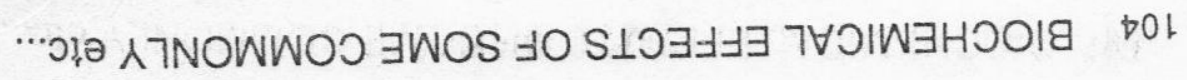


Table (l) : Fasting blood glucose level ( $\mathrm{mg} / \mathrm{dl})$ in alloxan diabetic rats before and after feeding termis and helba mixture.

\begin{tabular}{|l|c|c|}
\hline & Before eating & After eating \\
\hline Mean & 178.6 & 108.3 \\
\pm S. E. M. & \pm 9.75 & \pm 3.04 \\
P & & $0.001^{* *}$ \\
\hline
\end{tabular}

Table (II) : Total cholesterol, triglycerides, HDL-cholesterol and LDL (mg/dl) in alloxan diabetic rats before and after feeding termis and helba mixture.

\begin{tabular}{|l|c|c|c|c|c|c|c|c|}
\hline & \multicolumn{4}{|c|}{ Before eating } & \multicolumn{3}{c|}{ After eating } \\
\cline { 2 - 8 } & $\begin{array}{c}\text { Total } \\
\text { cholesterol }\end{array}$ & $\begin{array}{c}\text { Trigly- } \\
\text { cerides }\end{array}$ & $\begin{array}{c}\text { HDL } \\
\text { cholesterol }\end{array}$ & LDL & $\begin{array}{c}\text { Total } \\
\text { cholesterol }\end{array}$ & $\begin{array}{c}\text { Trigly- } \\
\text { cordes }\end{array}$ & $\begin{array}{c}\text { HDL } \\
\text { cholesterol }\end{array}$ & LDL \\
\hline Mean & 224.3 & 176.8 & 34 & 160 & 188.3 & 58.5 & 57.2 & 119.11 \\
\pm S. E> M. & \pm 12.59 & \pm 5.37 & \pm 3.5 & 13.58 & \pm 3.66 & \pm 5.41 & \pm 1.41 & \pm 4.58 \\
P & & & & & $0.02^{*}$ & $0.001^{* *}$ & $0.001^{* *}$ & 0.005 \\
\hline
\end{tabular}

* Significant.

** Highly Significant. 


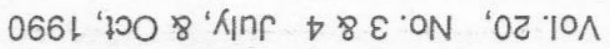

pue 0 'zl!ueg : ' $\angle t-\nabla t$

$$
266-686
$$

$:(7) \angle S$ "IOS 'Hnd : (8L6L)

's 7 'uesuar pue $\wedge$ 'a 'әn!nnew

'ẹ़u

-jom!leo 'solit so7 'suo!t

-eग!ाqnd ןeग!paw ә6ueา

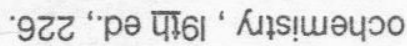

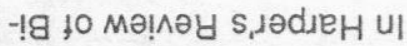

: (ع86เ) 'M ^ 'иәмроч

pue $\forall \cdot d^{\prime}$ 'sakew 'Ar 'M a 'ulpew

$$
\downarrow \varepsilon-\varsigma 己:(1) 6 \varepsilon \text { ' }
$$

u!lo i $u \forall:$ (†86L)

$\forall \cdot \exists$ ' 'buneh pue $\cdot 0 \cdot \mathrm{d}$

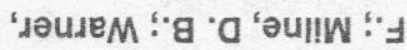

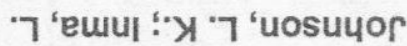

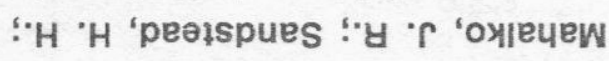

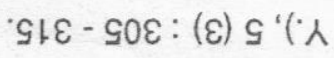

'N) 'səy ' यnN : (s86L) 'N

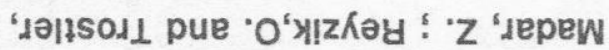

$$
\varepsilon 6 \varepsilon-88 \varepsilon:(\varepsilon) 8 \varepsilon
$$

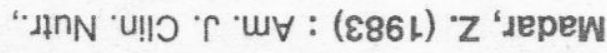

$$
\cdot 96 \varepsilon-68 \varepsilon
$$

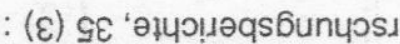

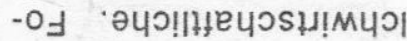

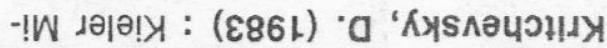

$$
\triangleright \varepsilon 9-129
$$

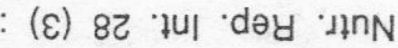

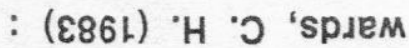

-pz pue 'S rumpry

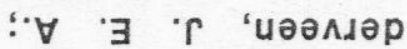

-uen "

: 182 个 pow 29 : (0861)

"ן je

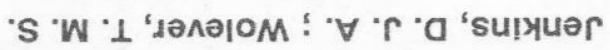

$$
9-t \nabla<1
$$

i! ? pow $2 \mathrm{dg}:(8 \angle 61)$

"je to 'y 'meyou!n pue

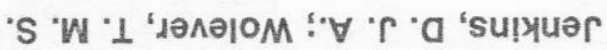

$$
01-1: 86 \text { ". }
$$

r uekq!7: (6L6L) 'w :

'seasp $\exists$ pue $\exists \cdot \forall$ 'uem

-so : $w$ 'w 'jueqezjaw

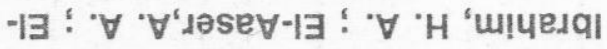

$$
002-681
$$

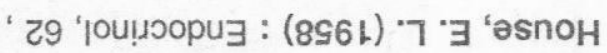

IS - E†O : LZ ג决N U!।

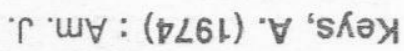

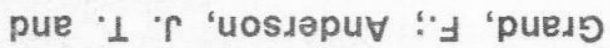

66 : 81 "шәчว

'u!l : (ZL6L) "ן tө ріемәрә!ды

$\rightarrow \varepsilon: 9 L Z$ paw $r \cdot 16 u \exists$

NON : (L96L) 'S 'ty 'sәอ7

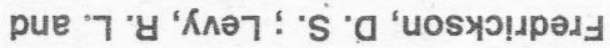

$6 L$ : 01 'யәуч

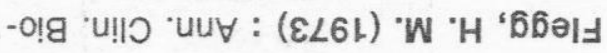

$$
8 \angle S-\varepsilon \angle S:(s) 91
$$

"jul dəu 'dinn : (LL61)

' $\forall$ 'w 'uosuyo pue ' $M \cdot 7$ ' $w$ 'bueuo

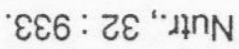

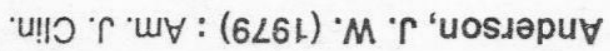

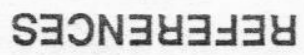

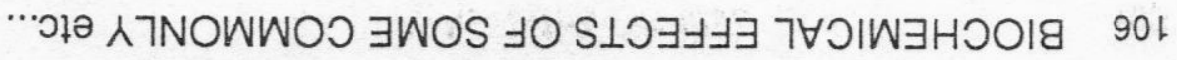


Holt, S. J. (1973) : F. Scarborough, B. D. (1970) : PhysiolCell. Sci., $13: 297$ - 315.

Miranda, P. M. and Howwitz, D. L. (1978): Ann. Intern. Med. $: 88: 482-6$. ogy and Biochemistry, Ninth edition, Churchill Livingstone, Endinburgh, London, New York, 18 : 366.

Qureshi, A. A.; Din, Z. Z.; Abuirmelleh, N.; Burger, W. C.; Ahmad, Y. and Elson, C. E. (1983) : Warnick, G. R.; Benderson, V. and J. Nutr., 113 (9) : 1746 Albers, N. (1983) : Clin. 55. Chem. 10:91 - 99 .

Roy, D. M. and Schneemen, B. O. Williamson, J. R. and Lacy, P. E. (1981) : J. Nutr., 111 (5) : (1959) : Arch. Path., 67 : $878-885$. $102-109$. 


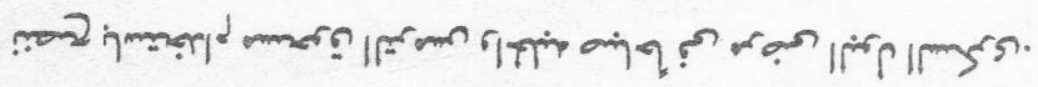

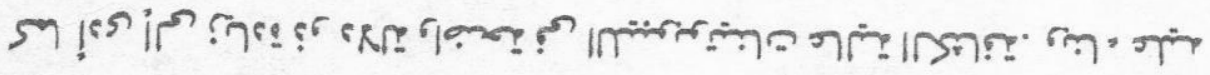

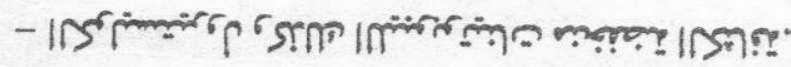

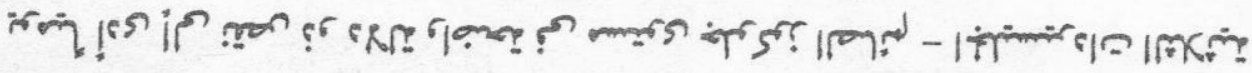

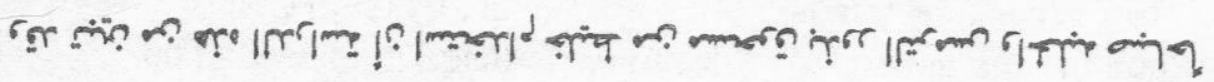

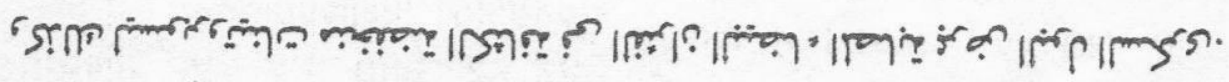
ব์

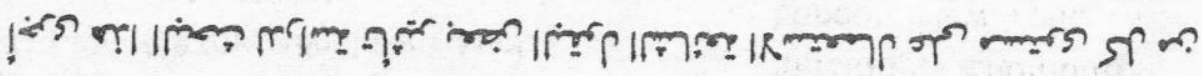

\section{iman imen}

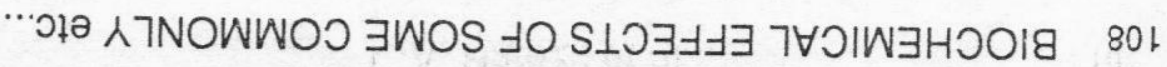

